\title{
ASSESSMENT OF THE EFFECTIVENESS OF SOCIAL PROGRAMMING
}

\author{
Venelin Terziev \\ Academician of the Russian Academy of Natural History, Moscow, Russia, Prof. \\ D.Sc.(Ec.), D.Sc. (National Security), D.Sc. (Social Activities), Ph.D., National Military University, \\ Veliko Tarnovo, Bulgaria; University of Rousse, Rousse, Bulgaria, terziev@skmat.com
}

\begin{abstract}
The entire diversity of assessments made by various subjects, going through certain procedures and stages in the assessment process, turns into resultant (final) assessments. As a rule, the organizational assessment process of the final information can serve as a basis of certain important practical conclusions for the implementation of relevant events and actions, development of programs to increase effectiveness.
\end{abstract}

Keywords: assessment, social programing, social efficiency, social activities, social progress.

\section{INTRODUCTION}

Starting point of our scientific research, directed to the assessment of the effectiveness of social programming, shall be the objectives and tasks of social activity, which definition depends on the level of its implementation. In other words, they can be defined at a national and regional level, at a settlement level, at a group level or at an individual level. Accordingly, the criteria for assessment of the effectiveness of the objectives achieved in the field of social activity and the related social programming are also determined.

Research in this direction allows us to determine the quality characteristics of the applicability of the system of criteria for assessment of the effectiveness of social activity. We can mention the following:

- To express to efficiency of all kinds, forms and methods of social services to the population;

- To show how effective the work of the public administration are, in particular social services in modern Bulgarian conditions relating to the conduct of continuous and complex reforms;

- To reflect the degree of efficiency of the management of the entire process of targeted and systematic social work with the population and the individuals in need of professional social assistance.

Accordingly, several approaches to determine the effectiveness of the implemented specific social activity at a national and local level, can be formulated.

The first will be associated with the most objective assessment of the ratio between the results achieved or the effect and the related costs. A key issue in this case becomes both the measuring and description of the results (effects), and the costs. As far as the cost could be estimated and planned, the efficiency of social services could be estimated, planned, actual, actually reached.

Another approach focuses on the assessment of the efficiency of social work from the standpoint of determining the degree of satisfaction of social needs and the expectations of the clients served, in their 
capacity as users, beneficiaries of the project or the program. Of crucial significance in this case are the subjective assessment methods, i.e. opinions, judgments, statements (on someone, something that is more or less specific), the particular subject, conducting the assessment of the effectiveness of the social activity. Therefore, in this case it is of utmost importance to identify and choose the information source of assessment. This is the subject, holding significant media assessment information, in the face of managers, specialists, representatives of supervisory bodies, users, etc. Of course, we should take into account that assessment information derived from specific people has always been subjective. The more individuals there are in the assessment process, the more, and in other equal conditions, such an assessment will aim at finding an objective and truthful picture of the activities of the social services and the implementation of the specific social employment program (project).

The complex character of the assessment also implies a targeted organization of the process of revealing of opinions, judgements and inference, expressed by certain forms and methods. In this case, we are dealing with the procedural and organizational significance of the concept of "assessment of the effectiveness of social services". Pursuing the achievement of a certain goal or the evaluation of a certain process, or a person, it is necessary to organize the evaluation process. To this end, we should provide and process sufficient assessment information, create and use certain assessment procedures, which include the appropriate instruments and sophisticated methods to verify the assessments.

The entire diversity of assessments made by various subjects, going through certain procedures and stages in the assessment process, turns into resultant (final) assessments. As a rule, the organizational assessment process of the final information can serve as a basis of certain important practical conclusions for the implementation of relevant events and actions, development of programs to increase effectiveness (Georgiev, 2016; Georgiev, 2017-a; Terziev, Kanev, 2019; Terziev, 2019a-k).

Among the factors allowing formulation of the objectives and tasks for assessment of the effectiveness of social services, we will list the following:

- The analytical capabilities of the social service to identify and assess the „inquiries”;

- The resources of the social service to operationally meet the „inquiries”;

- The potential of the social service (including the level of interaction with government, municipal, nongovernmental organizations and companies);

- The socio-economic conditions in the administrative territory in which the social service operates;

- The qualifications of the personnel of the social service.

\section{ASSESSMENT OF THE EFFECTIVENESS OF SOCIAL PROGRAMMING}

Special attention in assessing the effectiveness shall be paid to the special problem of quality assessment.

Indeed, many issues are solved in the light of quality, as indicators (experts) appear to be both the subjects for management of the activities of the social service and the objects of its activity. The most typical operation in quality assessment is ranking. We call the objects (phenomena, processes) ranked if any of their quantified changes is in accordance with a certain quality which they possess in a certain degree. In the practice of the various social services, ranking can be used in different situations. One of the most typical is the arrangement of the objects (processes phenomena) in terms of their placement in space and time, in accordance with the level of expression of a quality which cannot be measured by any objective scale, according to some measurable or liable to reporting features (as a rule the degree of expression of a quality, according to which ranking takes place, can always be practically measured), in compliance with a quality that is generally measurable, but at the time cannot be measured for practical or theoretical reasons (Terziev, Kanev, 2019; Terziev, 2019a-k; Terziev, 2018-d).

A typical example in the use of expert assessments in management could be the developed matrix on the "goal- means" correlation. The boxes of this matrix shall be filled at the end with information derived from the results given by the expert assessments.

The methods for assessment of the effectiveness in the social protection system are quite diverse, which is determined primarily by the subject to be assessed. We will provisionally call these methods "first row". Each subject for assessment may be more detailed and then, accordingly, new methods from the "second row" will appear. Every kind of social services (social-household, social-medical, social-legal, social-rehabilitation, social-psychological, social-advisory, material assistance) corresponds to a specific methodology for assessment of the effectiveness. 
In the analyzes of the existing concepts of effectiveness of the social services, respectively the national social policy, the theory of organization and administrative management defines the efficient management as a ratio of the pure positive results (exceeding desired consequences over undesired) and the eligible costs. A decision may be called effective if the best result is achieved in the given temporary costs or if the result is obtained at the lowest cost for the choice.

In addition to the "economic" component of the concept of effectiveness (the ratio between the volumes, provided services to the value or volume of resources needed to provide the volume of services), we can also note the "technical" or organizational part, determined by the positions for reaching the goals. The technical efficiency indicates the extent of compliance of the social services with the needs, desires and resources of their clients.

The problem of social efficiency is closely intertwined with the problem of the safety of the social system. In statistical aspect, under safety of the social system, we shall understand a specific area of a territory, the condition of this system, whose parameters are determined by a historically conditioned public ideal. For the contemporary Bulgarian society in particular, going abroad, beyond the border of the defined territory means getting closer of the society to some other variety.

Very important for this study are the scientific developments, which reveal the problem of effectiveness of the different social measures or technologies.

Social technology is a method of management of social processes, which provides the system with consistent actions of the individual, the team, the management bodies of the region, district, municipality and the settlement. The model of „Technologization” of the social space is expressed in an arrangement through the presented in it social objects and processes by set of signs, properties, characteristics, nature of formation, manifestation and reproduction. It is more appropriate to evaluate technologies in terms of optimality of the way for achieving the set objective and ensuring the achievement of certain results.

The effectiveness of social technologies can be assessed on the basis of the recent widespread assessment studies. Assessment studies can be conducted by both the developer and the assignor of the social technology. It is also important to emphasize that it can be carried out both at the stage of development, and at the stage of implementation of the technology.

The practice of the assessment studies can be oriented not to the entire technology, but to a separate part of it. It should be noted that in an assessment study of the process there is orientation toward the internal characteristics of the technology, allowing the evaluation of its positive and negative qualities.

In this case, the productive and implementation strategies of research orientation go over to search and evaluation of external effects, or towards its productivity.

Assessment of the effectiveness of technology can also take place through the application of various models - targeted and non-targeted. The targeted model for assessment studies is aimed at evaluation of the objectives themselves, the compliance of social technology of the set objectives and determination of the extent of their implementation. In this case, the quality of reporting and the list of potential objectives that may be related to the specific social technology, are assessed. In the basis of such an assessment, analytical and expert methods can be applied. The actual technological procedures are assessed in terms of their relevance to the objectives set. The efficiency of technology is higher if it corresponds to the set objectives.

The untargeted assessment study is aimed at detecting obvious or latent effects of the social technology. The assessment of the efficiency of the social technology relates to the complexity of the set of expected effects: on the one hand, there is poly-modality of the real effects of the object, subject and the social technology itself as a means, and on the other hand- there is no adequate valid document for their measuring.

The effectiveness of social technologies can be also measured by comparing the possible levels of activity. The first level shows that it can be achieved with existing resources and restrictions without technology deployment. The second level is related to the deployment of specific technologies given the existing resources and restrictions, and the potential in the development of technological means used, the removal of restrictions of a different kind. In addition, we can talk about the limits of growth of efficiency of social technology in the presence of resource constraints for its implementation.

The effectiveness of social technology is determined by both subjective and objective factors. To the first, we should refer the individual characteristics of the people, involved in the realization of a particular technology, the level of their professional training and status. To the objective factors, we can refer the factors for activity 
organization: the objective conditions of the environment, the workplace organization, the flow of information, the control over the activity.

In theory and practice, a number of attempts have been made to describe the methodology for assessment the effectiveness of social programs (projects), representing a complex of social measures, united by a common goal. The applicability of the social programs in our country, directed primarily towards social protection of the population, is based on this common goal.

Typical for the programs for social protection of the population, implemented by the state social services in Bulgaria, is that the existing system of social protection of the population and its social services is primarily focused on the „process”.

One of the instruments available to amend the situation and shift the attention to the efficiency of budget expenditures is the assessment of social programs. The assessment not only attracts the attention of state bodies to the diagnostics of the results and effect achieved (both by quantitative and qualitative methods), but also improves the analytical base, increases the knowledge of the social services. It allows the raising of the right and timely questions, the development of analytical approaches to the decisions for spending budget and attracted funds and in the development or adjustment of the social policy. In particular, this concerns the following questions: Does the program reach the set goals? Is the social assistance provided specifically to those for which it has been intended? Is employment provided to the appropriate beneficiaries? Is there a leak of budget funds to those who do not need assistance or inclusion in the program? Are there any administrative barriers to the access to the program? How do the achieved results relate to the money spent?

All these and other questions formulated during the assessment of the social program outline the circle of really meaningful, clear and scalable tasks within the intermediate or long-term development of the social protection of the population.

Budget constraints are only one of the external factors determining the need to assess the efficiency of spending of the budget funds. Public pressure by the population, being the potential voters, is another key factor in stimulating the deployment of the assessment. Each of the developed social programs reflects particular interests of society, for example, to reduce the number of homeless people on the streets and the number of young people suffering from drug addiction, to increase the number of socially active old people in the local community, to reduce the number of unemployed persons from vulnerable and risk groups, etc. The political pressure by voters on the one hand, and the budgetary constraints on the other, determine the need for analysis of the concrete results from the social program funded by the state budget and by the attracted funds. The assessment provides to the national and regional state authorities a complete, reasonable, objective information about the program results and the efficiency from the course of its implementation. Thus, the assessment is a tool for feedback between the representatives of the authorities, the beneficiaries and the program. The information, obtained during the assessment also the promotion of a specific program in the local community.

The interim assessment, which sets as objective an analysis of budget expenditures and the attracted resources in the implementation of the program, allows the revealing of the reasons for the discrepancy between the estimated and actual data. Sometimes the error can lie in the estimates of unrecorded number of external factors affecting the expenditure of the program. The assessment allows timely detection of such factors for impact, which allows the adjustment of the estimates for the program costs based on more accurate factual data.

The assessment also serves as a basis for the adoption of weighted economic and political rational decisions concerning the implementation of the program, as well as its timely correction. Of crucial importance to us is the possibility to compare social programs with other forms of social support in situations of budget cuts and the need to adopt decisions on the extension of funding.

Very often, in the course of realization of the social program, new mechanisms for provision of services are used - systems for search and selection of clients, collection schemes for payment, structures and schedules to provide this or that service, etc. A well-conducted assessment can detect errors in "the design" of the program or arising in the course of its implementation difficulties, which allows improving the mechanism for the provision of services, achieving their greater efficiency at lower cost. Furthermore, the assessment allows managers and specialists of the program to provide more clearly a comprehensive picture of the program implementation, including means to achieve the final results. The opportunities for assessment on removing barriers between business and local authorities are determined by the assessment results, insofar as they allow dispelling the bias in government efficiency and control. Not only the population, but also business structures sometimes have a too remote idea of what local authorities do to improve the prosperity of the 
residents of the city or municipality. The assessment causes the different groups of economic agents, in particular the business, to think about the efficiency of social programs, the possible ways to improve them from the point of view of the local population, the opportunities to bring their own contribution to solving local problems.

In order for the assessment to be efficient, it should not depend only on the opinions of the managers of the program. In other words, the decision to conduct or order an assessment should be within the competence of people standing over the management of the specific program. An important means for keeping the objectivity is the attraction of independent experts, having no personal or professional interest in the results of the assessment. In order to have practical orientation and useful results, the assessment should take into account the opinion of specialists - practitioners (e.g. social workers or social services employees), as well as of the clients (the users) of the program. Specialists and users provide relevant information on various aspects of the program implementation, arising difficulties and ways to overcome them.

In order for the assessment to be reliable, it should be carried out by specialists, using consistent modern standards of methodology. In addition, the information on the assessment results should be available to the main interested parties and should be considered by as wide range of specialists as possible, who are involved in the implementation, financing or development of the social program. Thus, the primary method, used to determine the efficiency of state programs for social support of the population, are the assessment studies of various performance indicators at all stages of implementation of the program. In particular, this concerns the following:

at the stage of development: the program project is assessed by qualitative indicators of the fixed in it basic value reference points (degree of compliance of the objectives of the creators of the program with the objectives of the socio-economic development of the country, the declared legal norms and principles, as well as the expectations of the subjects of the program);

at the implementation stage: the efficiency of the program, expressed in qualitative indicators of the organizational, legal and management components in the implementation of the program (a condition for the efficient social state government appears to be the presence of an effective mechanism for coordination of the social impacts in state social service - an executor of the program);

at the final (assessment) stage: the program is assessed by quantitative indicators of the economic component of efficiency (correlation of the volume of services and their value in terms of limited human and material resources) and qualitative indicators (the degree of compliance of the objectives of managers and organizers of the program with the needs of the subjects of the program).

Given the entire multi-aspect character of the assessment of the effectiveness of social programming and its product - the social program, in the context of the management by results, in compliance with the principle "what-if", according to the social work priorities, stemming from the dynamic changes within the social environment, we consider appropriate to offer a model for assessment of the effectiveness, based on the approach of "organizational effectiveness".

In the basis of such a model is the combination of certain elements such as a system for acquisition of resources, choice of objectives, assessment of the impact of the external environment and the choice of strategy. In the context of the nature of the social development, we believe that the presence of the specified elements to a greater extent can meet the effectiveness requirements of a given social program. In order for the social program, as a set of social measures (specific actions with specific deadlines) carried out by the authorities and structures for social activities, aimed at the implementation of a certain goal, to be assessed as effective, it should be secured in terms of resources, should have a clearly defined purpose as a final result, consistent with the dynamic social environment, the achievement of which to be based on the choice of an appropriate strategy, contributing to the achievement of the targeted final result. And all this depends on the way of transformation of resources in the necessary social skills, to the benefit of the social policies. We should also point out that with „social skills” we mean the ability to perform certain actions to achieve a certain goal or targeted result under certain conditions and in accordance with certain standards and social policies. This is also the reason for our choice of the "organizational effectiveness" approach for the purposes of the model, proposed by us, proven as a good management practice in the implementation of the "resources, capabilities, benefits (results)" correlation .

In the formulation of the model, we direct our attention to the entrance of the organization (the Ministry of labor and social policy (MLSP), social services at different levels of management). Basically, this is the system for acquisition of resources, which are necessary for the implementation of the social program, in order to implement a certain social policy as a targeted result. This means that the system for acquisition of resources is in direct correlation to the objectives and the potential of the social department and social 
services. Since every particular resource has a different user in time, the need of ongoing supervision over them is also determined.

Hence, the appearance of the system for acquisition of resources, as the first element of the model proposed by us, is shown in Fig.1, which shows the presence of these two groups of correlations: resources, organization- objectives and specific resources-potential-strategy.

The first correlation, resources-organization-objectives, shows the resources, which are necessary, in order to achieve the objectives set in the social field with a certain social program for social protection.

The second correlation, specific resources-potential-strategy, is more specific and shows, given the specific resources at the entrance and the available potential (capabilities) of the state, represented by the Ministry of labor and social policy, respectively social services at different levels of management, what strategy/strategies should be implemented in order to achieve the set objectives for the implementation of the social policy.

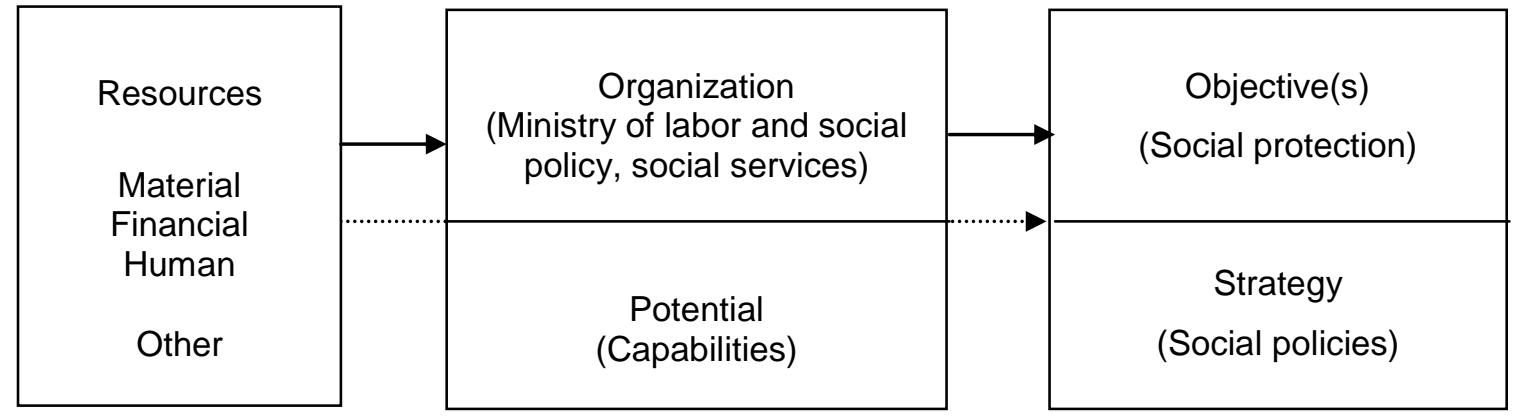

Fig.1.System for acquisition of resources

The second element of the model is related to the choice of objective and focuses on the exit, setting the level of achievement of the preliminary set objective. In other words, how to transform the resources at the entrance in order to achieve the objective, which is shown on Fig. 2

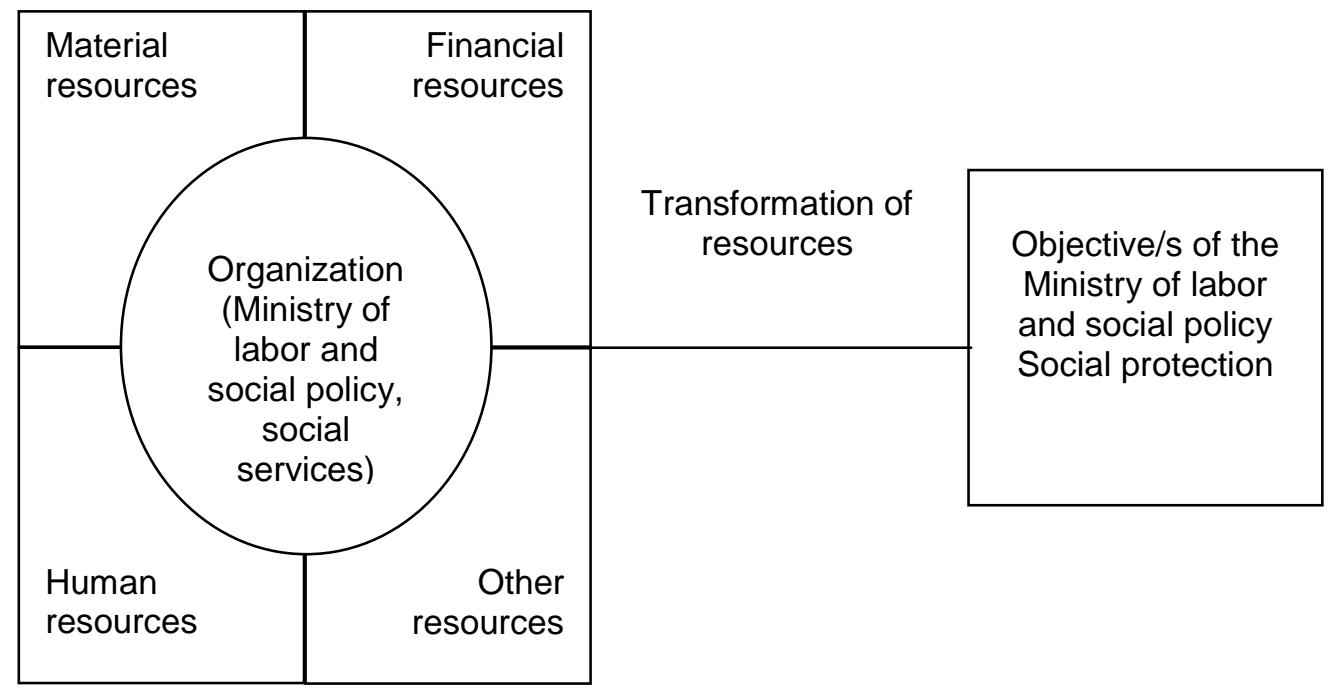

Fig.2.Choice of an objective

The third element in the model is the assessment of the external impact. The most important thing here is to bring the impact of the external environment to a minimum and maximize the benefits of achieving the objectives. This means that a correct assessment of the impact of the external factors is necessary, which is to a greater extent directly related to the fourth element- the choice of strategy. In order to make such a choice, the priorities of the social policy should be determined, as the areas of impact should be listed according to their importance, in compliance with the potential (capabilities), the interaction with the organizational environment, the direction and strength of the external pressure, the priority areas of the social policy future.

In accordance with the above, the summarized model for assessment of the effectiveness of social programming, based on the approach of organizational effectiveness is shown in Fig.3. 


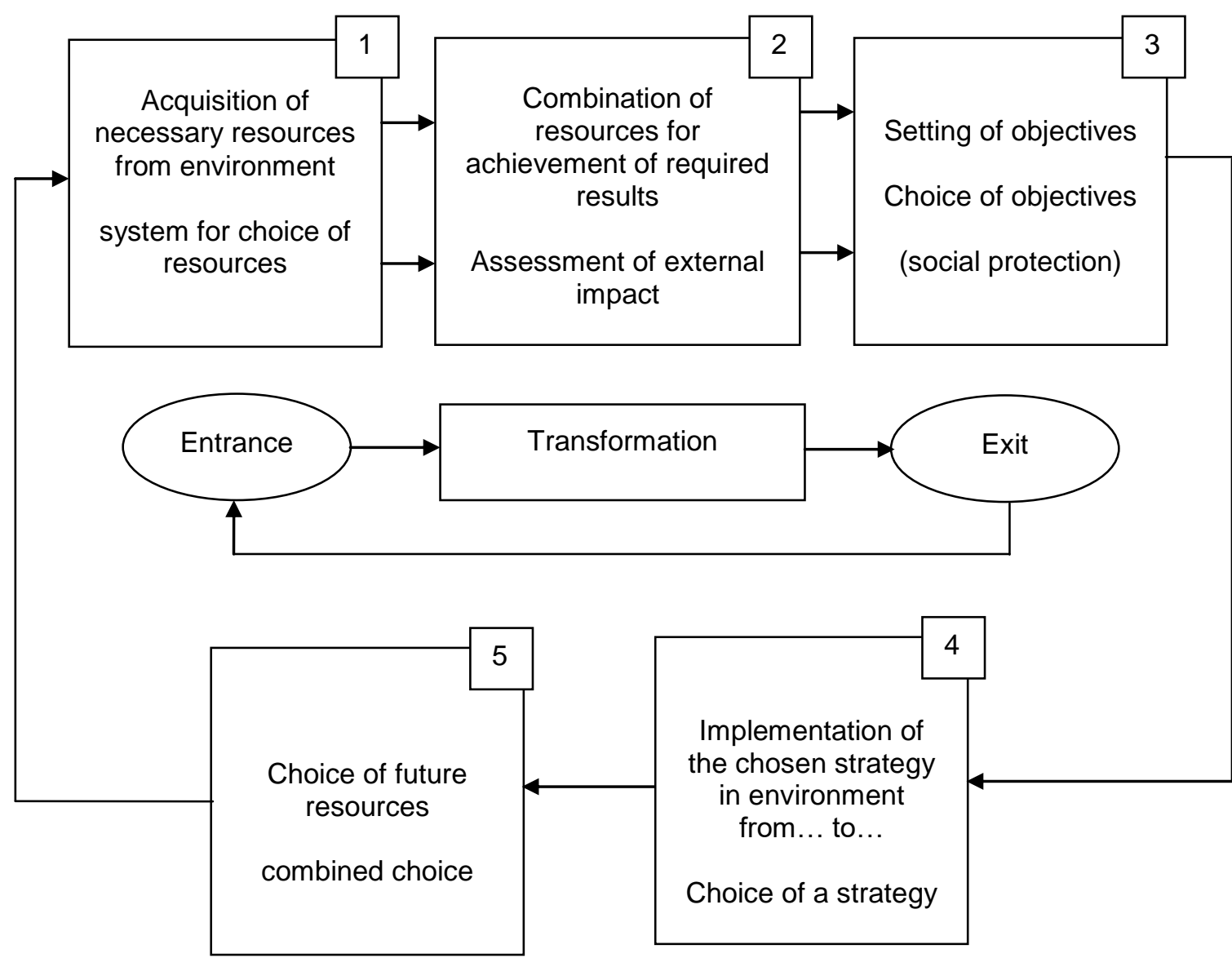

Fig.3.Model for assessment of the effectiveness of social programming, based on the approach of organizational effectiveness

It is noteworthy that the so presented model is a cyclical process associated with the targeted management. In other words, the objective is examined as a desired condition, and the results- as achieved objectives. On this basis, the correlations are the following:

Resources-assessment of the impact of the external environment (Fig.4);

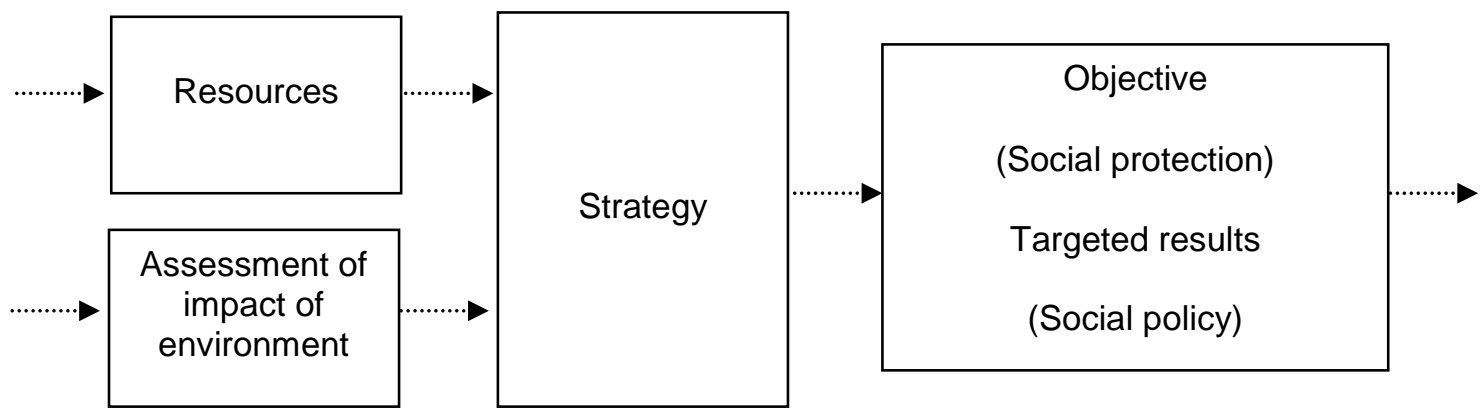

Fig.4. "Resources - environment - results achieved (objective, benefits)" correlation

Achieved objective (achieved result) - management decision (in compliance with the changes in the social environment) - new objective (Fig. 5); 


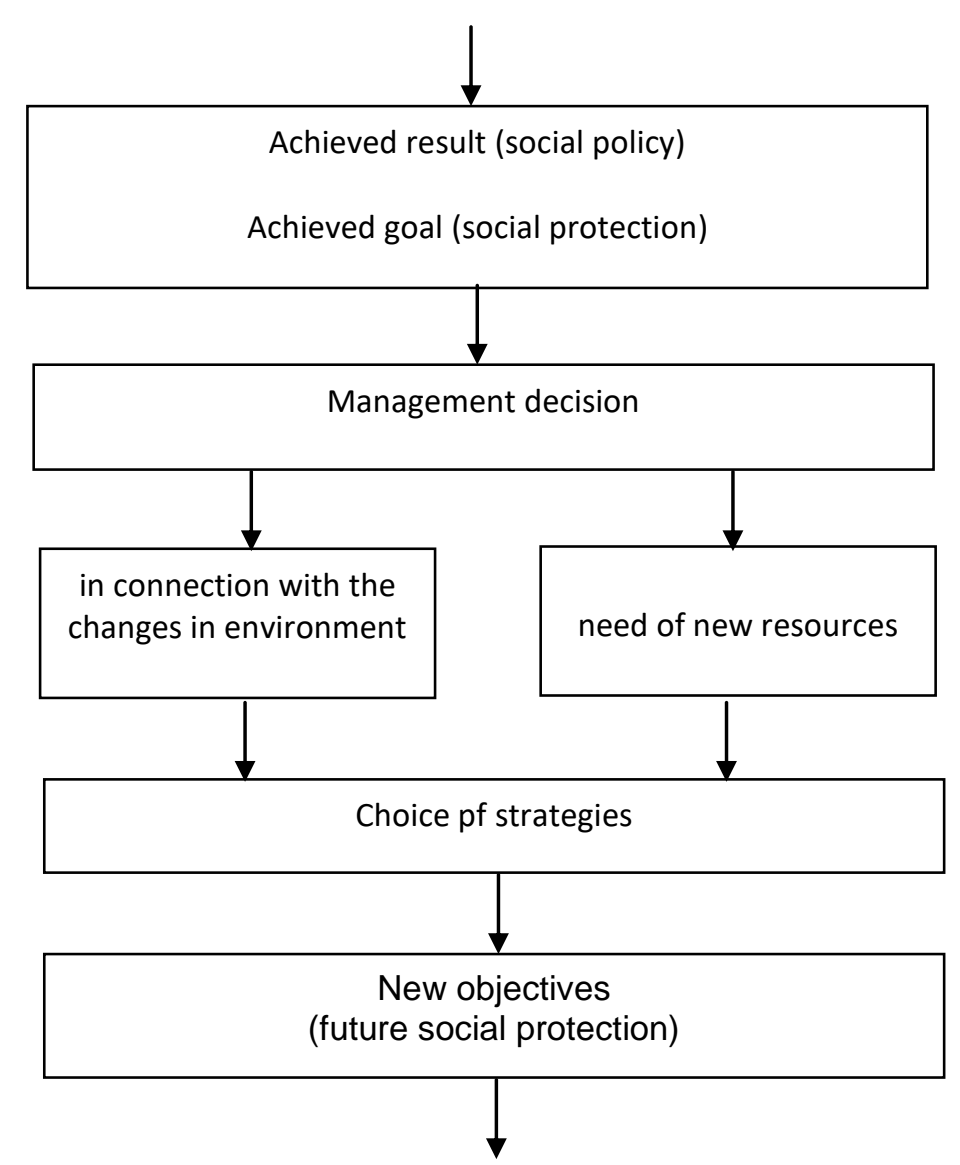

Fig. 5. "Achieved result-decision-new objective" correlation

The two specified correlations are related to the benefits (effects), which means that the practical implementation of the proposed model is in the assessment of the degree of implementation of the objectives (results) set by the social program, expressed in the assessment of the effectiveness of social programming, when taking into consideration the multi-aspect character of the dynamic social environment (Terziev, Kanev, 2019; Terziev, 2019a-k; Terziev, 2018-d; Terziev, Georgiev, 2018e-f).

\section{CONCLUSION}

To summarize the above, we present the following conclusions and recommendations related to social programming and its importance for regulation of the social development. Studied as a social phenomenon, social programming and its conceptual-categorical apparatus is required to help answer the questions about the content and the forms of programming, its place and role in the theory and practice of public management.

- The modern consideration of programming as a general principle of management, is associated with preliminary planned future actions and activities aimed at achieving a certain goal with certain means, in accordance with the challenges of the dynamic changes in the social environment on the basis of alternativeness of the decisions and optimal choice, contributing to the management by results. Programming, as the basis of management in the public sector, and in particular the management of resources of the state, is an intermediate stage between planning and budgeting in the implementation of the social policy of the state.

- The concretization of the objectives of the social management is carried out through the social program, as a structured dynamic image and a way of action for coordinated interaction between the bodies of power, which allows the solution of important social problems according to their resource commitment, executors and deadlines for the implementation of a set of tasks and measures.

- The effectiveness (economic and social) of the operating and developing social system, is always the result of the actions of all factors of the system as a whole, presented as an integrative productivity. Consistency and complexity of the relationship between economic and social effectiveness is determined by the methodological principle, which states that the implementation of the social program becomes in itself a catalyst for effective socio-economic development. 
- The validity of the objectives and tasks to assess the effectiveness of social services in Bulgaria, to provide stability and support to disadvantaged people (vulnerable groups on the labor market), known as risk groups, is determined by the analytical capabilities of social service for identification and evaluation of the „inquiries”, resource availability of the social service to meet the „inquiries”; the level of interaction between the institutions at a government (national), municipal and non-governmental level; socio-economic conditions and qualifications of the personnel of the social service.

- The theoretical and pragmatic overview of social programming allows the application of an appropriate methodology for the development of an active social program, which primary goal is determined by the faster level of knowledge, prediction and achievement of socially significant consequences for the future in the forming of the general public process.

- For the assessment of the effectiveness of the social program, the determination of exact criteria, specific reference points and specific indicators is necessary, which can serve as formally adopted standards for social service and as parameters of the program itself.

The multi-aspect character of the assessment of the effectiveness of social programming and its product- the social program, in the context of the management by results, in compliance with the principle "what-if", according to the social work priorities, stemming from the dynamic changes within the social environment, determines the need of an appropriate model for assessment of the effectiveness, based on the approach of "organizational effectiveness" (Terziev, Arabska, 2014; Terziev, 2015-b; Terziev, Arabska, 2016a).

\section{REFERENCE LIST}

Georgiev, Marin. (2016). Obshtestvenoto i ikonomichesko razvitie v konteksta na sotsialnite politiki. // Spisanie za nauka "Novo znanie“. Visshe Uchilishte po Agrobiznes i Razvitie na Regionite, 5, 2016, N 4, str. 26-41, ISSN 2367-4598 (Online), (Print) ISSN 1314-5703 (Георгиев, Марин. Общественото и икономическо развитие в контекста на социалните политики. // Списание за наука „Ново знание“. Висше Училище по Агробизнес и Развитие на Регионите, 5, 2016, N 4, стр. 26-41, ISSN 2367-4598 (Online), (Print) ISSN 1314-5703.

Georgiev, Marin. (2017). Sbalansirovannaya karta kak alyternativa malogo biznesa. // Innovatsionnie tehnologii $v$ nauke novogo vrmeni, Sbornik statey Mezhdunarodnoy nauchno - prakticheskoy konferentsii 1 fevralya 2017 g., Ufa NITS AETERNA, Chasty 1, 2017, s. 43-49, ISBN 978-5-00109004-5, ISBN 978-5-00109-007-6 (Георгиев, Марин. Сбалансированная карта как альтернатива малого бизнеса. // Инновационніе технологии в науке нового врмени, Сборник статей Международной научно - практической конференции 1 февраля 2017 г., Уфра НИЦ АЭТЕРНА, Часть 1, 2017, с. 43-49, ISBN 978-5-00109-004-5, ISBN 978-5-00109-007-6).

Georgiev, Marin. (2017a). Impacts of active social programs on labor market. // Mezhdunarodnayy nauchnayy zhurnal «Innovatsionnaya nauka». NITS Aeterna, N 02-1, 2017, pp. 139-143, ISSN 24106070 (Georgiev, Marin. Impacts of active social programs on labor market. // Международный научный журнал «Инновационная наука». НИЦ Аэтерна, N 02-1, 2017, pp. 139-143, ISSN 24106070).

Terziev, V., Kanev, D. (2019). Modern developments in behavioral economics. // Smart Technologies and Innovations in Design for Control of Technological Processes and Objects: Economy and Production Proceeding of the International Science and Technology Conference "FarEastCon-2018" Volume 138, October 2-4, 2018, Vladivostok, Russian Federation, pp. 10-23, 2019, (Print) ISBN978-3-030-15576-6, (Online) ISBN978-3-030-15577-3.

Terziev, Venelin. (2019a). Provision of integrated employment and social assistance services in Bulgaria. // Smart Technologies and Innovations in Design for Control of Technological Processes and Objects: Economy and Production Proceeding of the International Science and Technology Conference "FarEastCon-2018" Volume 138, October 2-4, 2018, Vladivostok, Russian Federation, pp. 24-39, 2019, (Print) ISBN978-3-030-15576-6, (Online) ISBN978-3-030-15577-3.

Terziev, Venelin. (2019b). Problems of control in the social sphere. // INTCESS 2019- 6th International Conference on Education and Social Sciences, 4-6 February, 2019, Dubai, International Organization Center of Academic Research, Istanbul, Turkey, pp. 577-593, ISBN: 978-605-82433-5-4.

Terziev, Venelin. (2019c). The criterion "competence" in the economic sector. // INTCESS 2019- 6th 
International Conference on Education and Social Sciences, 4-6 February, 2019, Dubai, International Organization Center of Academic Research, Istanbul, Turkey, pp. 1241-1247, ISBN: 978-605-824335-4.

Terziev, Venelin. (2019d). Social policy and labor market development in Bulgarian transition period. // INTCESS 2019- 6th International Conference on Education and Social Sciences, 4-6 February, 2019, Dubai, International Organization Center of Academic Research, Istanbul, Turkey, pp. 703-714, ISBN: 978-605-82433-5-4.

Terziev, Venelin. (2019e). Theoretical basis of development of labor market and social policy in the republic of Bulgaria. // INTCESS 2019- 6th International Conference on Education and Social Sciences, 4-6 February, 2019, Dubai, International Organization Center of Academic Research, Istanbul, Turkey, pp. 715-726, ISBN: 978-605-82433-5-4.

Terziev, Venelin. (2019f). The problem of social efficiency- Indicators for social efficiency. // INTCESS 20196th International Conference on Education and Social Sciences, 4-6 February, 2019, Dubai, International Organization Center of Academic Research, Istanbul, Turkey, pp. 669-678, ISBN: 978605-82433-5-4.

Terziev, Venelin. (2019g). Experiencing social policy development and efficiency measurment. // INTCESS 2019- 6th International Conference on Education and Social Sciences, 4-6 February, 2019, Dubai, International Organization Center of Academic Research, Istanbul, Turkey, pp. 679-686, ISBN: 978605-82433-5-4.

Terziev, Venelin. (2019h). Efficiency and assessment of social technology. // INTCESS 2019- 6th International Conference on Education and Social Sciences, 4-6 February, 2019, Dubai, International Organization Center of Academic Research, Istanbul, Turkey, pp. 687-694, ISBN: 978-605-82433-5-4.

Terziev, Venelin. (2019i). Conceptual framework of social adaptation. // INTCESS 2019- 6th International Conference on Education and Social Sciences, 4-6 February, 2019, Dubai, International Organization Center of Academic Research, Istanbul, Turkey, pp. 494-503, ISBN: 978-605-82433-5-4.

Terziev, Venelin. (2019j). The dependence social adaptation- socialization. // INTCESS 2019- 6th International Conference on Education and Social Sciences, 4-6 February, 2019, Dubai, International Organization Center of Academic Research, Istanbul, Turkey, pp. 478-485, ISBN: 978-605-82433-5-4.

Terziev, Venelin. (2019k). Social activity and human resources as social development factors. // INTCESS 2019- 6th International Conference on Education and Social Sciences, 4-6 February, 2019, Dubai, International Organization Center of Academic Research, Istanbul, Turkey, pp. 546-553, ISBN: 978605-82433-5-4.

Terziev, Venelin. (2018). The active model of a social programme and its strategic advantage . // ADVED 2018- 4th International Conference on Advances in Education and Social Sciences Abstracts \& Proceedings, 15-17 October 2018- Istanbul, Turkey, International Organization Center of Academic Research, www.ocerints.org, Istanbul, Turkey, 2018, pp. 189-203, ISBN: 978-605-82433-4-7.

Terziev, Venelin. (2018a). Active social programs development in Bulgaria: contemporary challenges and social management instruments. // ADVED 2018- 4th International Conference on Advances in Education and Social Sciences Abstracts \& Proceedings, 15-17 October 2018- Istanbul, Turkey, International Organization Center of Academic Research, www.ocerints.org, Istanbul, Turkey, 2018, pp. 149-163, ISBN: 978-605-82433-4-7.

Terziev, Venelin. (2018b). Social assistance services and integrated employment in Bulgaria. // ADVED 2018- 4th International Conference on Advances in Education and Social Sciences Abstracts \& Proceedings, 15-17 October 2018- Istanbul, Turkey, International Organization Center of Academic Research, www.ocerints.org, Istanbul, Turkey, 2018, pp. 164-177, ISBN: 978-605-82433-4-7.

Terziev, Venelin. (2018c). Impact of the labor market policies for ensuring employment. // ADVED 2018- 4th International Conference on Advances in Education and Social Sciences Abstracts \& Proceedings, 1517 October 2018- Istanbul, Turkey, International Organization Center of Academic Research, www.ocerints.org, Istanbul, Turkey, 2018, pp. 178-188, ISBN: 978-605-82433-4-7.

Terziev, Venelin. (2018d). Importance of human resources to social development. // ADVED 2018- 4th International Conference on Advances in Education and Social Sciences Abstracts \& Proceedings, 1517 October 2018- Istanbul, Turkey, International Organization Center of Academic Research, www.ocerints.org, Istanbul, Turkey, 2018, pp. 204-212, ISBN: 978-605-82433-4-7. 
Terziev, V., Georgiev, M. (2018e). A strategic framework for the development of social entrepreneurship in Bulgaria. // Knowledge - International Journal, August 2018, Institute of Knowledge Management, Skopje, Macedonia, 25, 2018, N 1, pp. 23-34, ISSN 1857-923X (for e-version), ISSN 2545 - 4439 (for printed version).

Terziev, V., Georgiev, M. (2018f). Support for the development of social entrepreneurship in Bulgaria. // Knowledge - International Journal, September, 2018, Institute of Knowledge Management, Skopje, Macedonia, 26, 2018, N1, pp.57-74, ISSN 1857-923X (for e-version), ISSN 2545 - 4439 (for printed version).

Terziev, V., E., Arabska. (2014). Assessment of active social policies' impacts on labor market in the Republic of Bulgaria. Kolektivnaya monografiya "Sotsialyno-ekonomicheskie i pravovay razvitiya ekonomiki“, Ufa, Aeterna. Rossiya, 2014. ISBN 978-5-906769-97-8, str. 3-57 (Terziev, V., E. Arabska. (2014). Assessment of active social policies' impacts on labor market in the Republic of Bulgaria. Колективная монография „Социально-экономические и правовы развития экономики“, Уфа, Аэтерна. Россия, 2014. ISBN 978-5-906769-97-8, стр. 3-57).

Terziev, Venelin. (2015). Impact of active social policies and programs in the period of active economic transformations in Bulgaria,,East West”Association for Advanced Studies and Higher Education, Vienna, 2015, ISBN 78-3-903063-44-0, 434 p.

Terziev, Venelin. (2015a). Assessment of active social policies impact of social policies on transformation processes in bulgarian economy, Moscow, 2015, Publisher „Перо“, 110 p.

Terziev, Venelin. (2015b). Opportunities for improving the efficiency of the social adaptation of servicemen discharged from military service in Bulgaria:- Novosibirsk: Publisher CRNS, 2015. ISBN 978-5-00068402-3, $270 \mathrm{p}$.

Terziev, V., E., Arabska. (2016a). Effektivnoe vliyanie na raynok truda posredstvom uluchsheniya realizatsii sotsialynoy politiki. Novosibirsk: Izdatelystvo TSRNS, 2016. ISBN 978-5-00068-496-2, $312 \mathrm{str}$ (Терзиев, В., Е. Арабска. (2016а). Эффрективное влияние на рынок труда посредством улучшения реализации социальной политики. Новосибирск: Издательство ЦРНС, 2016. ISBN 978-5-00068-496-2, 312 стр). 